\title{
小児腎臓移植レシピエント選択基準についての検討
}

\author{
長谷川 友紀 ${ }^{* 1}$ 雨 宮 浩*2 高 原 史 郎*3 大島 伸 - *4 \\ 高橋 公太 ${ }^{* 5}$ 深 尾 立*6 寺 岡 慧*7 北川 定謙*8 \\ 東邦大学医学部公衆衛生学教室 ${ }^{* 1}$ 国立小坚病院小児医療研究センター*2 大阪大学医学部泌尿器科*3 \\ 名古屋大学医学部泌尿器科*4 新潟大学医学部泌尿器科 $* 5$ 筑波大学臨床医学系外科*6 \\ 東京女子医科大学腎臟病総合医療センター第 3 外科*7 埼玉県立大学*8
}

key words：腎藏移植，献腎移植，慢性腎不全，レシピエント選択基準，HLA

〈要旨〉

日本では献腎数の不足のため末期腎不全患者の大部分は慢性透析により治療されている. 特に小児の末期腎不全 患者は慢性透析では成長障害を防ぐことができないため腎蔵移植のよい適応である。（社) 日本臓器移植ネットワー クは 1997 年 10 月に新しい小児のレシピエント選択基準を導入し, ドナーが 15 歳以下の場合には 15 歳以下の献腎 移植希望登録者を 16 歳以上に比較して優先して取扱うように改め, 該当者がいない場合には旧基準が用いられる. 本研究ではこの新基準の有効性を検討するためにシミュレーション・スタデイーを行った。

(社) 日本臟器移植ネットワークの登録情報に基づいて 15146 人の希望登録者と 19 人のドナーを仮定し,ドナーか ら得られた 38 個の献腎が新・旧基準に基づいてどのレシピエントに移植されるかを解析した. 新基準は 38 例中 37 例 (97.4\%) に適応され，新基準を用いた場合には旧基準に比較してレシピエントの年齢は若く（13.8 歳 vs 47.5 歳), 待機期間はより短かった ( 28.4 か月 vs 71.0 か月). 反面, HLA 抗原の平均適合数はより少なく (HLA-DR 抗 原で 1.68 個 vs 1.84 個, HLA-A，B 抗原で 1.68 個 vs 2.50 個), 同一都道府県内での移植成立はより少数であっ た $(2.6 \%$ vs $29.0 \%)$. 新基準の導入は 15 歳以下の小児献腎移植希望登録者がレシピエントとして選択される可能 性を高めるものの, HLA 適合数の低下, 長距離の臓器搬送が移植成績に及ぼす影響については今後の検討課題であ ると結論された.

\section{Effectiveness of the new donor-recipient matching rule of cadaveric kidney transplantation for children}

Tomonori Hasegawa*1, Hiroshi Amemiya*2, Shiro Takahara*3, Shinichi Oshima*4, Kota Takahashi*5, Katashi Fukao*6, Satoshi Teraoka*7, Sadayoshi Kitagawa*8

Department of Public Health, Toho University School of Medicine*1 ; National Children's Medical Research Center $^{* 2}$; Department of Urology, Osaka University School of Medicine*3 ; Department of Urology, Nagoya University School of Medicine*4 ; Department of Urology, Niigata University School of Medicine*5 ${ }^{*}$; Department of Surgery, Institute of Clinical Medicine, University of Tsukuba*6 ; Third Department of Surgery, Kidney Center, Tokyo Women's Medical College*7 ; Saitama Prefectural University*8

Because of a shortage of cadaveric kidneys in Japan, the majority of patients with end-stage renal disease (ESRD) are treated with chronic dialysis. Children with ESRD are good candidates for renal transplantation because chronic dialysis can not prevent growth impairment. In October 1997, the Japan Organ Transplantation Network introduced a new donor-recipient matching rule for cadaveric kidney transplantation in children. Recipients aged 15 or below take precedence over recipients aged 16 or over when kidneys are donated from donors aged 15 or below. When no suitable recipients are found, the previous matching rule is then applied. We performed a simulation study to evaluate the effectiveness of the new matching rule. Based on registration data of the Japan Organ Transplantation Network, 15146 recipients and 19 donors were assumed. The new matching

長谷川友紀 東邦大学医学部公衆衛生学教室

干 143-8540 大田区大森西 5-21-16（03-3762-4151）

Tomonori Hasegawa Fax 03-5493-5417

〔受付：平成 11 年 4 月 23 日，受理：平成 11 年 7 月 15 日〕 
rule was effective for 37 of 38 donations (97.4\%). With the new matching rule, the recipients were younger (new vs old rules; 13.8 years vs 47.5 years) and waited for shorter periods (28.4 months vs 71.0 months). The average number of HLA matches (human leukocyte angigens) was lower (1.68 vs 1.84 in HLA-DR, 1.68 vs $2.50 \mathrm{HLA}-\mathrm{A}$ and $\mathrm{B}$ antigens), and fewer transplants were made within the same prefecture where the donation was made $(2.6 \%$ vs $29.0 \%)$. We conclude that the new rule is expected to increase the chance of transplants in younger recipients, although the possible adverse effects of low HLA matching and long distance transportation of donated kidneys are to be investigated.

\section{緒言}

15 歳以下の小児の末期腎不全患者は, 全透析患者の $2.0 \%$, 献腎移植希望登録者（以下「希望登録者」とい う)の $0.4 \%$ を占める ${ }^{1,2)}$. 小児末期腎不全患者ではたと え慢性透析により老廃物の除去を行い生命の維持を 行った場合においても成長障害を生じるため，骨端線 閉鎖以前の腎臟移植が治療法として望ましい。日本で は欧米と比較して人口当たりの献腎数が少なく慢性透 析に依存する割合が高いという特徴を有するが，小児 末期腎不全患者では，成人に比較して事態はより深刻 である。(社) 日本臟器移植ネットワークでは，小児末
期腎不全患者に対して 1997 年 10 月よりレシピエント 選択基準を改定し，15 歳以下の小児ドナーからの献腎 については 15 歳以下の小児希望登録者を優先するよ うに改め，小児における腎臟移植の拡大を図った（表 $1)^{3)}$.

\section{I. 目 的}

本研究では, この新基準が小児レシピエントの選択 拡大につながるか否かをシミュレーションにより検討 した.

表 1 小児献腎移植レシピエント選択基準

\begin{tabular}{|c|c|c|}
\hline $\begin{array}{l}\text { 旧基準 } \\
\text { 1. ABO 玨 } \\
\text { 2. HLA 政 } \\
\text { ただ } \\
\text { 3. HLA i }\end{array}$ &  & $\begin{array}{l}\text { 也はブロック内で検索を行う。 } \\
\text { を優先する. }\end{array}$ \\
\hline \multicolumn{3}{|c|}{ 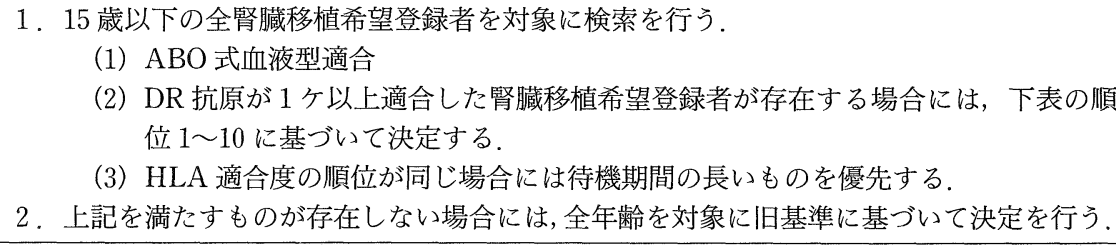 } \\
\hline \multicolumn{3}{|c|}{ （下表） HLA 適合度と優先順位 } \\
\hline 順位 & DR 座の適合度 & $\mathrm{A}$ 座および B 座の適合度 \\
\hline 1 & 2 & 4 \\
\hline 2 & 2 & 3 \\
\hline 3 & 2 & 2 \\
\hline 4 & 2 & 1 \\
\hline 5 & 2 & 0 \\
\hline 6 & 1 & 4 \\
\hline 7 & 1 & 3 \\
\hline 8 & 1 & 2 \\
\hline 9 & 1 & 1 \\
\hline 10 & 1 & 0 \\
\hline 11 & 0 & 4 \\
\hline 12 & 0 & 3 \\
\hline 13 & 0 & 2 \\
\hline 14 & 0 & 1 \\
\hline 15 & 0 & 0 \\
\hline
\end{tabular}


表 2 新・旧基準でのレシピエント選択の結果 $(\mathrm{n}=38)$

\begin{tabular}{|c|c|c|c|}
\hline & 新基準 & 旧基準 & $\mathrm{p}$ \\
\hline $\begin{array}{l}\text { レシピエント平均年齢 } \\
\text { (歳, 平均士SD, （）内は範囲) }\end{array}$ & $\begin{array}{c}13.8 \pm 4.9 \\
(10.0 \sim 40.8)\end{array}$ & $\begin{array}{c}47.5 \pm 9.5 \\
(26.1 \sim 66.8)\end{array}$ & $\mathrm{p}^{* *}<0.01$ \\
\hline $\begin{array}{l}\text { レシピエントのうち } 15 \text { 歳以下の割合 } \\
\text { (全移植数に対する\%) }\end{array}$ & $97.4 \%$ & $0.0 \%$ & $\mathrm{p}^{*}<0.01$ \\
\hline $\begin{array}{l}\text { 平均待機期間（月） } \\
(\text { 月, 平均士 } \mathrm{SD}, （ ） \text { 内は範囲) }\end{array}$ & $\begin{array}{l}28.4 \pm 19.9 \\
(1.0 \sim 83.0)\end{array}$ & $\begin{array}{l}71.0 \pm 62.5 \\
(5.0 \sim 274.0)\end{array}$ & $\mathrm{p}^{* *}<0.01$ \\
\hline $\begin{array}{l}\text { DR 抗原平均適合数 } \\
\text { (個, 平均 } \pm \mathrm{SD} \text { ) }\end{array}$ & $1.61 \pm 0.50$ & $1.84 \pm 0.37$ & $\mathrm{p}^{* *}<0.05$ \\
\hline $\begin{array}{l}\mathrm{AB} \text { 抗原平均適合数 } \\
\text { (個, 平均土 } \mathrm{SD} \text { ) }\end{array}$ & $1.68 \pm 1.16$ & $2.50 \pm 1.20$ & $\mathrm{p}^{* *}<0.01$ \\
\hline $\begin{array}{l}6 \text { 抗原適合 } \\
\text { (全移植数に対する\%) }\end{array}$ & $10.5 \%$ & $23.7 \%$ & $\mathrm{~ns}^{*}$ \\
\hline $\begin{array}{l}\text { 同一ブロック内での移植 } \\
\text { (全移植数に対する\%) }\end{array}$ & $23.7 \%$ & $81.6 \%$ & $\mathrm{p}^{*}<0.01$ \\
\hline $\begin{array}{l}\text { 同一都道府県での移植 } \\
\text { (全移植数に対する \%) }\end{array}$ & $2.6 \%$ & $29.0 \%$ & $\mathrm{p}^{*}<0.01$ \\
\hline
\end{tabular}

\section{II. 対象と方法}

シミュレーションでは，希望登録者，小児ドナーの 集団を想定し，後者から提供された腎臓に対して前者 からどのようなレシピエントが選択されたかを新・旧 基準のそれぞれを用いて明らかにする。希望登録者と しては 1998 年 10 月時点で(社) 日本藏器移植ネット ワークに登録している 15146 人と，年齢，待機期間， 登録都道府県, ABO 式血液型, HLA 抗原型が全く同 じ集団を想定した。 小児ドナーとしては，1995 年 4 月 1 日より 1998 年 3 月 31 日までの 3 年間に実際に献腎 を行った 15 歳以下のドナー 19 人と年齢, 死亡都道府 県, ABO 式血液型, HLA 抗原型が全く同じ集団を想 定した. 実際には医学的理由等により 19 例は必ずしも 1 人につき 2 腎を提供していないが，シミュレーショ ンでは 19 人はそれぞれ 2 腎ずつ, 合計 38 個の献腎を 行ったものと想定し，旧基準と新基準のそれぞれを用 いて希望登録者からレシピエントを選択した場合の, 移植が行われる地域, HLA 抗原の適合度, レシピエン トの平均年齢，待機期間等を明らかにした. シミュ レーションにあたっては 38 個の献腎の発生順序は考 慮せず，希望登録者からレシピエントが選ばれると同 時に，選ばれたレシピエントと全く同じ属性・待機期 間を有する希望登録者が出現し希望登録者集団に加わ るものと仮定した。

\section{III. 結 果}

希望登録者の平均年齢 47.2 歳, 平均待機期間は
69.7 か月である. 希望登録者のうち 15 歳以下は 61 人 であり，平均年齢は 12.4 歳，平均待機期間は 23.1 か 月である。ドナーの平均年齢は 9.3 歳（1１5 歳）で あった。表 2 に新・旧基準を用いたレシピエント選択 の結果を示す。新基準では, 15 歳以下の登録者を対象 とした検索で $97.4 \%(37 / 38)$ で新基準 1 に合致するレ シピエントが見い出された．新基準では旧基準に比較 して，15 歳以下の小児がレシピエントとして選ばれる ことが多く，平均待機期間は短かった。また全国に散 在する比較的少数の 15 歳以下の登録者からレシピエ ントが選ばれるため HLA-DR，HLA-A，B 抗原の適 合度は低くなり，同一都道府県内，ブロック内での移 植成立割合は減少することが示された。

\section{IV. 考 察}

献腎数の不足している状況において新基準は小児末 期腎不全患者のおかれた状況に配慮し，15 歳以下のド ナーからの献腎については 15 歳以下の小児登録者に 優先して移植を行うことを目的に導入された。 小児希 望登録者に対する優先的取扱いはUNOSにおいては ドナーの年齢とは無関係に 18 歳未満の希望登録者に は年齢に応じたポイントを与えることにより行われて いる4). 日本では小児ドナーからの献腎について別個 の基準を設けることにより達成を図っている，日本に おいては献腎数が米国に比較して圧倒的に少なく少々 のポイントを小児希望登録者に与えても移植機会を増 やすことは難しいと思われ，小児ドナーからの献腎に ついて別個の基準を設けることは合理的であると思わ れる。本研究の結果は，新基準は小览ドナーからの献 
腎の多くに適応が可能であり一定の実効性を有するこ とを示唆する. 反面，小児希望登録者は比較的少数で 全国に散在するため, HLA 抗原の適合数は低下し, 長 距離の腎臟搬送を必要とすることが併せて示唆され た．新基準の妥当性・有効性の検討には，今後, 新基 準に基づいた小児移植事例と従来の移植事例との生着 率・生存率等の成績の比較検討を行う必要がある。

本研究の一部は平成 10 年度厚生科学研究費補助金感覚 器障害および免疫・アレルギー等研究事業「臟器移植の社 会的資源整備に向けての研究」として行われた。

\section{文献}

1）日本透析医学会統計調査委員会：わが国の慢性透析療 法の現況（1997 年 12 月 31 日現在）。透析会誌 $32 ： 1^{-}$ 17, 1999

2）（社）日本臓器移植ネットワーク年齢別・性別献腎移植 登録者数平成 8 年 12 月 31 日現在爫 1

3）臟器提供者（ドナー）適応基準及び移植希望者（レシ ピエント）選択基準について。平成 9 年 10 月 16 日健 医発第 1371 号 社団法人日本臟器移植ネットワーク 理事長宛 厚生省保健医療局長通知

4) 3.5 Allocation of Cadaveric Kidneys, Policies of Organ Distribution, United Network for Organ Sharing*2

*1 http://www.medi-net.or.jp/tcnet/JKTN/stat/stat 01.html

※2 http://www.unos.org/About/policy_policies3_5.htm 